\title{
Performance of Mergers and Acquisitions under Corporate Governance Perspective
}

\author{
- Based on the Analysis of Chinese Real Estate Listed Companies \\ Yong Liu, Yongqing Wang \\ School of Business Administration, South China University of Technology, Guangzhou, China \\ Email: bmdoer@163.com
}

Received 2013

\begin{abstract}
This paper investigates the impact of mergers and acquisitions (M\&A) on corporate performance. This article selects 36 M\&A cases of China's listed real estate companies in Shanghai and Shenzhen Stock Exchanges from 2008 to 2009. Regarding the corporate value in 2011 as the measure of the long-term performance, we will explore the relationship among check-and-balance Ownership Structure, board size, and institutional investors impact the performance. This paper concludes a positive impact ownership structure on the M\&A performance. In addition, the empirical analysis reveals that that the board size has a significant negative effect on the performance. Additionally, the results of the paper indicate that the CEO-Chairman duality has a significant impact on the long-term performance. Besides, institutional investors have positive effect on M\&A performance.
\end{abstract}

Keywords: Corporate Governance; M\&A; Long-Term Performance; Real Estate

\section{Introduction}

Mergers and acquisitions as growth strategies have received attention from developed as well as emerging economies. In the 21st century, the global M\&A transactions created a new record both in quantity and scale. Clearly, the M\&A activity has become an important way to seek resources and development. M\&A, however, can really make a profit for the enterprise, or increase the shareholder's wealth? It has also been an academia controversial problem. Since the first M\&A case of listed company come out in China, the number of such cases have grown with each passing day. Increasing competitions in the Chinese market lead to constant take over activities and gradual expansion of acquisition scale, the cumulative volume of business transactions of M\&A hit 910.9 billion Yuan in 2006-2009, which is 40 times as much as that in the period of 2002-2005. Under the environment of market economy, companies can achieve its goal by accumulating internal resource and the mergers and acquisitions. George Stigler noted that no companies can grow without merge and acquisition to some extent. Large companies can hardly grow by organic business expansion, as a source of growth is particularly evident in developing country. Therefore, M\&A exerts an important influence on the development of the industry.

In the American history, there were five waves of mergers and acquisitions. Facing with the offensive threat of the multinational enterprises, the companies of China should enhance their comprehensive competitive power through the local merge and acquisition as to improve their inferior position in the area of resources and market after entering WTO. Affected by the global financial crisis, the number of M\&A transactions in 2008 was only 1441, a sharp drop by $18.73 \%$ compared with that in 2007. But the total transaction turnover still hit 488.81 19 billion Yuan, increasing by $10.85 \%$. These statistical data are well-explained the trend of M\&A transactions. In addition, the trend of M\&A has moved away from poorly-related acquisitions that diversify business to highly-related acquisitions that focus their advantage.

M\&A transactions are significantly different in number and volume of trade in different industries. Facing the financial and market pressures, many real estate companies, especially the leading ones, purchased some small firms. In 2008, the industry of manufacturing and real estate are the most active ones in merger and acquisition activity, much more than the rest.

The world has experienced a few large tides of mergers and acquisitions, promoting the development of the country and boosting the modernization of the industrial structure. Real estate industry has an important impact on the whole national economy. Today, the impact of these merger and acquisition activities on the enterprise performance is worth of some academic study. To understand the impact of M\&A on performance, managers can make correct strategy. Small investors can reduce investment risks, and increase return on investment (Guo \& Chen, 2013). Therefore, this paper is of practical and theoretical significance. Compared with related research, this paper has several contributions as follows:

Firstly, this paper comprehensively analyzes the influences of Corporate Governance on acquiring companies' M\&A performance. While researching M\&A transactions, many scholars have brought ownership structure into their study scope. But, they mostly focused on the influences of ownership concentration and ownership nature, and rarely investigated the effect of check-and-balance relationships among big shareholders in ownership structure. What's more, this paper take institutional investors and CEO duality into consideration .Therefore, this paper contributes to the extension and perfection of researches on influencing factors of M\&A performance.

Secondly, this paper also examines factors that may influ- 
ence the M\&A performance. Those factors were selected partly with the help of literature analyses and partly in virtue of model deductions. And the final empirical tests found that these factors had indeed impacts on the performance. On one hand, it is the further validation of existing research results, and on the other hand it also provides new theoretical perspectives and empirical evidence, which makes the research on corporate governance and M\&A performance more detailed and complete.

The remainder of the paper is organized as follows. Section 1 presents the literature review. Section 2 introduces to the current situation of real estate in China. Section 3, the paper puts forward four hypothesizes. Section 4 presents data selection and the analysis model results. Section 5 discusses the conclusions and their implications. At last, we make several suggestions for further study.

\section{The Literature Review}

With acceleration of the economic globalization process, the worldwide market competition is becoming increasingly intense. Merger is widely considered to be a significant tool by the enterprises looking for an unbeaten success in the fierce competition. Since 1980s, three major merger waves have swept China in several decades, while counterpart of which in western countries takes more than one hundred years. Essentially, only successful merger could help enterprises to enhance its business performances, and it is the result of a game played by multiple sides to determine whether the merger effects are taken advantage of or not. Thus, clarifying the influences of merger on business performances of listed companies in China, studying the trend of changes of merger performances, and offering practical countermeasures and suggestions would be meaningful both from theoretical and practical perspectives to enhance merger performances, exploit cooperative merger effects, regulate stock capital market and maintain stability of financial market.

Why do companies choose merger? Broadly speaking, there are three main reasons: 1 ) economies of scale theory: mergers and acquisitions among enterprises will lead to lower marginal costs and the improvement of the competition; 2) synergistic effect: The synergies gained from the merger would lower the cost and increase the efficiency of resource allocation; 3) Diversification Management Theory: the company can maintain financial stability, reduce asset and risk diversification. M\&A are one of the mechanisms by which firms gain access to new resources; via resource redeployment, they increase revenues and reduce cost. Limited resources should be transferred from the inefficient enterprises to the high efficient ones, which is conducive to the optimization of resources and the formation of large companies. Mergers and acquisitions in this process play a vital role in industry consolidation.

In the previous studies, scholars have come to inconsistent conclusions on the effect of acquisition. Some (Phalippou \& Gottschalk, 2009; Jang \& Liu, 2012) concluded that the acquiree usually gets higher returns although the acquirer has certain advantages. Yu (2011) found that M\&A did not improve the performance of the entire enterprise through the sample of Chinese stock market listed companies in 2007-2010. Rani et al. (2013) claimed that mergers and acquisitions have not resulted improvement in assets turnover ratios, as initially there might not be increase in sales and any consequently, further im- provement in combined capacity utilization may not be possible.

However, some studies indicate that M\&A appear to have been beneficial for the acquiring companies in the long-run with regard to their operating performance. The findings suggest that profitability of acquiring firms have improved during post-M\&A phase. Mergers and acquisitions have resulted to better and improved performance. Du \& Guo (2012) found that the M\&A is an important factor in promoting business growth, and the effect is more obvious after 2 or 3 years.

According to the existing literature, the study appears to opposite result, because they selected different performance indicators and control variables. Das et al. (2012) pointed out that the M\&A performance measures are diverse owing to heterogeneous views on what constitutes M\&A performance and organization performance. They are categorized under Accounting Measures, Market Measures and Other Measures, including subjective assessments. Hagendorff \& Keasey (2009) found that the long-term performance of M\&A is measured by the third year company value.

The transition is a characteristic of Chinese economy. In the current capital market system, mergers and acquisitions market are with distinct characteristics of the times. The market mechanism is imperfect, so the company relies on non-market system. In the current stage, the state-owned enterprises have the advantages of the government relations and market position.

The literature about corporate governance identifies three prominent parts: board, check-and-balance ownership structure and CEO duality. One other factor that may influence long-term performance was also analyzed in the paper-Institutional investors. OECD (2004) defines corporate governance is one of the key elements that improves a firm's performance, and the fluctuation of capital markets, stimulating the innovative activity and development of enterprises. However, Manpreet Singh Gill (2009) found that there is no unanimity among the researchers about the relationship between corporate governance and M\&A performance. One also finds that most of the work in this regard was done in the context of developed countries.

The logic of the paper reflects the relationship between long-term performance of M\&A and corporate performance (board of directors, institutional investors and equity balance). Hermalin et al. (2003) found that the board of directors' features can cause significant effects on shareholder value. Perry and Shivdasani (2005) stated, "Charged with hiring, evaluating, compensating and ongoing monitoring of the management, the board of directors is the shareholder's primary mechanism for oversight of managers”. Furthermore, Lei G. \& Song S. (2008) aimed to examine the influences of board composition and ownership structures on the firm performance. Their paper indicated that a strong positive relation between the level of ownership and performance. While no strong relation was found between the inside directors or level of managerial ownership and profitability in continental European companies. Hu (2012) contended that the board must oversee blind expansion and assertive behavior of the management. Based on a framework composed of structural, ownership, expertise, and prestige power of the board, Stephen V. Horner (2010) contributes to the role of agency theory in explaining corporate governance by extending upper echelons thinking to the study of boards. Zhou et al. (2013) believed that board of directors has different professional background, work experience and professional training, so they have a broader perspective to solve problems. The 
board can act as a strategic role in strategy formulation to check managerial opportunism. If corporate governance is in place, the management will make optimal strategic policies and end up making sub-optimal strategies, which can lead to sustainable competitive advantage (Luke H. Cashen, 2011). Large board size gives the firm a competitive edge in different fronts ranging from more expertise, experience, resource corporate strategy and provision of broad services. So, corporate governance structure can be a resource for the firm. Raheja C. G. (2005) researched optimal board size and composition under various conditions (the type of industry and industry characteristics). When the probability of passing bad projects is low, bad projects could directly affect the performance of the firm. Therefore, board size and composition could affect the performance of the company. Bello Lawal (2012) found that It is logical to first identify if board size affects quality of corporate board decision before moving further to ascertain whether such board decision has impact on firm performance (Board Size $\rightarrow$ Quality Decision $\rightarrow$ Firm Performance). Some studies (Mak \& Yuanto, 2003; Haniffa \& Hudaib, 2006; Garg, 2007) favor smaller board sizes. However, (Abidin et al., 2009) and Sulong \& Nor, 2010) favor large board sizes, (Dwivedi \& Jain, 2005; Jackling \& Johl, 2009) support large board size.

Francoeur et al. (2012) asserted that large shareholders have strong incentives to manage earnings upward prior to stockfinanced transactions to limit the dilution of their controlling position. Through mergers and acquisitions, Sarkar et al. (2000) found that the controlling shareholder improved the value of non-listed companies. In order to supervise managers, large shareholders involved in business management, so agency conflicts between managers and shareholders can be alleviated. Goranova et al. (2012) found that the second and the third largest shareholder's stake will constraint the largest shareholder, and improve corporate governance efficiency. Silveira \& Dias (2010) analyze the impact on market value of news about conflicts of interest between controlling and minority share-holders. They suggest that the actions of controlling shareholders that hurt minority shareholders are perceived as value destroying in a significant way. Minority shareholders may sell their stock with large losses and walk away. In firms with concentrated ownership, conflict of interest also exists between controlling owners (or block holders) and minority shareholders (Fan \& Wong, 2005). Institutional investors are found to improve the quality of corporate governance in financial reporting in cases where other important governance factors exist. Ben-Amar, Walid, \& Paul Andre (2006) found that maintaining harmonious corporate relationship with each stakeholder is of high strategic importance to the company and the delivery of success in the marketplace as well as the ability to add value for firms. Mehrdad Alipour \& Hossein Amjadi (2011) investigated the effect of ownership structure on performance of listed companies in Tehran Stock Exchange. Findings indicate that there is significant and negative relationship between "the amount of ownership of biggest shareholder" and firm performance, while "the amount of ownership of five greater share-holders" has positive effect. Besides, the relationship between "the amount of ownership of institutional shareholders" and "the amount of ownership of managerial shareholders" is significant and negative.

Chairman-CEO duality is defined in respect of one person heading both the Management and the Board. Masulis et al. (2007) concluded that Chairman-CEO duality in different in- dustries have different effect on the acquisition of wealth. The papers have been divergence about CEO duality and the effect of firm performance. The results ranges from positive (Coles et al., 2001) to negative and mix findings (Heracleous, 2001; Adams et al., 2005). Raluca-Georgiana (2013) use data of listed Romanian firms from the Bucharest Stock Exchange, and analyze the relationship between CEO duality and performance (ROA or ROE). Empirical findings indicate that CEO duality is positively related with performance. He concluded that the integrity of information available to board is compromised with CEO duality due to asymmetric as CEO determines what kinds of information are brought to board attention. Saibaba, M. D. (2013) examines the impact of board independence and CEO duality on the valuation of companies listed in BSE 100 index. The paper results show that CEO duality do not have a significant impact on firm valuations measured by Tobin's Q. The study also indicates that the firms with large board sizes have better valuation in the Indian context.

Wang Kun and Xiao Xing (2005) showed that, in the listed companies with the institutional investors in China, the amount of funds used by related parties was significantly lower, and the correlation between the share proportion held by institutional investors was significant negative. Yingzhao Li \& Jian Wei. (2011) classifie institutional investors into three types based on their investment behavior, and respectively research their influences to major shareholders' benefits transportation. Their paper indicates that, for their interests, active and passive institutional investors can effectively inhibit the benefits transportation behavior of large shareholders. And securities investment funds are the larger, higher shareholders in the company, which makes them not able to inhibit the benefits transportation behavior of large shareholders, even have "conspiracy" tendencies with the substantial shareholders.

From the above literatures, we can conclude that there is no exact answer to the relationship between the corporate governance and performance. Similarly, the relationship between M\&A performance and ownership structure is still ambiguous. The relationship may be either positive or non-existent.

\section{The Real Estate Industry}

The real estate is such kind of industry which is engaged in various economic activities such as development, investment, intermediary services, property management, rental and sales along with the links of production, circulation and consumption. The real estate, under the title of "GDP barometer", is sensitive to business cycle. There are three categories of real estate nowadays in China, the development, intermediary services and property management. The development of the real estate mainly involves in property and land development. The intermediary services aim at providing intermediary services for property circulation, including real estate brooking and appraisal. The property management aims at providing support for building, equipment and landscaping and services for security and cleaning. The real estate development is the head and front of real estate industry in China.

The motive for merge and acquisition in China as follows:

1) The obtaining of land resources

Land is essential and indispensable for the real estate. However, the land resource is limited, with the increasing growth of population and the sustainable economic development, the scarcity of land resources becomes more apparent. The contra- 
dictions among population, economy and land resources are inevitable, which result in the rise of land price. In the meanwhile, the Chinese government monopolizes the supply of land resources, the price, quantity, structure and direction of land supply will have influence on the development of real estate.

In recent years, the policies of credit, land and taxation carried out by government that meant to keeping down the housing price, also has effect on the cost for the real estate enterprises to hold land. Driven by these policies, the gap between the small and medium size real estate enterprises and the big one would widen, and some of those SME are doomed to be swallowed. The merge and acquisition of among the real estate business is imperative. The improvements made by the government in the land market also worsen the problem of the scarcity of the land resources. The land prices continue to rise, which imposes greater burden on the real estate companies. The large real estate enterprises could seize more land resources, lower the acquisition cost, expand their business and increase market share through the merge and acquisition of the small and medium size companies.

2) Expand new financing channels

The debt-to-assets ratio of real estate companies is generally high in China. Under the mode of operation on borrowings, the ability of fund procurement determines the maintenance of fund chain and influences the overall development of the real estate enterprises. And the back loan would be the most significant source of the industry fund. Now, there are still some rough edges in the real estate financial market system, the financing channel, especially the small and medium size companies restricted by their own conditions, is simple. Therefore, it's difficult for those kinds of companies to finance through IPO as they are more dependent on the back loan. However, by means of selling enterprises land and projects, seeking the opportunities to cooperate with others, the small and medium size companies could find the "short cut" to expand financing channels and free themselves from the constraints of capital.

3) Macroscopic regulation of government

As macroscopic regulation of government, the real estate business capital chain is day by day tight. Industry competition and potential operational risk lead to M\&A of real estate companies, besides, and M\&A achieves multiple business areas. Mergers and acquisitions have become an approach of risk diversification, and steady income. Real estate enterprises desire to expand non-residential business, such as commercial real estate, tourism projects and the traditional projects, which become an important means to resist risks.

4) Horizontal competition

Horizontal competition means the controlling shareholder or actual controller of listed companies engaged in the same or similar business, which may lead to compete with own business. Chinese law prohibits horizontal competition in the real estate industry, in fact there is still horizontal competition, and from now on we should solve it. M\&A is the most effective method to eliminate competition. So, M\&A reaches the aim of resource integration. Mergers and acquisitions can achieve economies of scale and further enhance its core competitiveness of the real estate business, which is in line with the long-term corporate strategic planning and protect the interests of minority shareholders and the long-term development of enterprises.

5) Corporate real estate

A feature of China's real estate enterprises about the number and scale: many small and medium real estate companies, but large real estate companies are relatively small. On the one hand, the acquired company can retain high-quality resources, loyal customers, good reputation, and other valuable advantages through the acquisition, which lay the foundation of new market areas. On the other hand, M\&A helps the acquirer to help enterprises enter new markets and avoid problems, so that enterprises can adapt to the new market environment with the fastest speed. Through mergers and acquisitions, the entire industry will integrate resources and improve the efficiency of resource use. What's more, M\&A improves the degree of market concentration and expand business scale, which improve the overall competitiveness of the real estate.

The above characteristics affect corporate governance. The current situation of corporate governance in real estate listed Companies. With economic development; investors began to concern the corporate governance of listed companies. They wanted to the board to make more accurate investment decisions. In the current circumstances of real estate listed companies, the characteristic of corporate governance as follows: First, the board size: The board size of listed real estate companies have reduced from the initial board size 16 - 28 people to 10 17 people, but there is still a gap compared with the optimal board size 7 - 9 people. The stakeholder theory and enterprise value maximization theory are familiar to us, so the number of Chairman-CEO duality is small. Second, the ownership structure: ownership structure can be subdivided into ownership attributes and ownership concentration.

In ownership concentration, the shareholding ratio of large shareholders is still at a high level. The average proportion of the largest shareholder is $40 \%$, while the top ten shareholders are less than the largest shareholder's stake, so the dominance of the large shareholder is quite serious.

In addition to the largest shareholder, the second largest shareholder and the second to the tenth largest shareholders cannot form an effective check and balances, that is to say, the first major shareholders have absolute power.

\section{Hypothesis}

As aforementioned, the analysis of existing literatures implies that:

1) Check-and-balance Ownership Structure helps resolve the agency problems and improve the firm's performance.

2) If board size increases, board become less effective and increases decision-making time.

3) There is influence CEO duality On the M\&A performance.

4) Institutional investors may affect the decision of board and long-term performance.

Different aspects of board structure, comprising board size and CEO duality, have become influential factors in the implementation of effective corporate governance of firms. However, the previous literatures have been showed mixed evidence about the factors. Therefore, the paper comes into sight to answer the above questions and put forward four hypothesizes.

\section{Ownership Control and Enterprise Performance}

Controlling shareholders have the incentives and power, with a large proportion of voting rights, to pursue their personal interests at the expense of minority shareholders (Wang Lijun, 2008; Fu Qiang, 2012). In fact, minority shareholders are difficult to fully understand the internal operation, because Chinese 
market rules and regulations are imperfect. The alignment effect dominates the entrenchment motives and acts as a deterrent mechanism to prevent controlling shareholders from managing earnings in M\&A. In state-owned enterprises, government will intervene in the company's decision. But the corporate internal governance structure will affect the realization of government. When the controlling shareholder's stake is higher, the ability of obtaining private benefits of control is higher, but they must bear the most of the losses and make its motivation of obtaining private benefits diminished. Therefore, the controlling shareholder in a lower shareholding, the motivation of merger and acquisition further deviate from the goal of profit, while controlling shareholder has a higher motivation of profit when at a higher stake. Therefore, the paper puts forward the first hypothesis: xinlunwen68.

Hypothesis 1: Under the lower shareholding, mergers and acquisitions' performance is negatively related to the controlling shareholder's ownership; under the higher stake, mergers and acquisitions' performance is positively related to the controlling shareholder's stake.

\section{Board of Directors and Corporate Performance}

The performance affected by the company's characteristics and the board micro decision-making mechanisms. The role of directors in corporate governance is strategic, monitor and control. The larger board members lead to communicate weak, allowing limited control of the management. Bedsides, trust and understanding between directors will be reduced. In China, the state-controlled real estate company has strong political overtones, so leaders' decision is important. For private listed companies, board members have close personal relationship with controlling shareholder, so board members will not cast opposing votes. Board size affects the quality of deliberation among members and ability of board to arrive at optimal corporate decisions. The board size represents the total head counts of directors seating on the corporate board. Majority of documented evidences have demonstrated that small boards are more efficient and effective. Taking into account the above equivocal findings, therefore, the paper puts forward the second hypothesis:

Hypothesis 2: the Board size is negatively related to Performance of M\&A.

\section{Institutional Investors and Corporate Performance}

Institutional investors mean that professional and independent investment as a corporate shareholder. One branch of the literature is consistent with institutional investors being better monitors than investors in general, which found that there is a positive correlation between the number and the percentage ownership of institutional investors and operating performance of large firms. In the mature capital markets, institutional investors have a strong impact on the enterprise. The minority shareholders have certain options to dig enough information and analyze the trend of company. But, due to legal constraints, institutional investors in the company's business decisions cannot play a direct role, who cannot act as the big shareholder in firms, so institutional investors have no strong motivation to care about the development of enterprises. Moreover, institutional investors tend to adopt a diversified investment strategy in order to avoid investment risks. Investment diversification reduces the enthusiasm of institutional investor to supervise the board. Now in China, the financial market is the lack of independence, and participants of the stock market are not mature. Besides, the insider trading is often exposed to the public. The relevant legal and rule is imperfect and incomplete, which leads to institutional investors conspire with the management for their own interests. Therefore, the paper puts forward the third hypothesis:

Hypothesis 3: Institutional investors are negatively associated with the long-term performance of M\&A.

\section{Chairman-CEO Duality and Enterprise Performance}

To our knowledge, in China's national conditions, the general manager has a good personal relationship with the president in private enterprises, especially the family company. While in the state-owned enterprises, the chairman and general manager are appointed by the relevant government departments. In the state-owned enterprises, Chairman-CE0 duality avoids replacing good CEO for some abnormal causes. CEO duality provides the company with a leadership core, and brings clear corporate strategy and mission. When companies are in fierce competition, decisive decision-making and clear strategic orientation help companies make acquisitions decisions in time. Accordingly, CEO duality would make the firm more stable and sustainable, which will lead to improve corporate performance. Therefore, the paper puts forward the fourth hypothesis:

Hypothesis 4: Chairman-CEO duality has significant impact on the on the M\&A performance.

\section{Data Selection and the Analysis Model}

\section{Sample and Variable Selection}

Selecting significant events of M\&A which happened in the real estate companies listed on the Shanghai and Shenzhen stock exchanges from 2008 to 2009, we obtain the resulting 36 samples of enterprise merger and acquisition. Excluding conditions as follows: 1) excluding acquisitions failed samples; 2) Excluding ST, * ST listed companies; 3) exclude the delisting of the company in 2008-2012; 4) the payment is less than $5 \%$ of acquirer company total assets.

In order to further scientific suitable empirical analysis, we use the following specific indicators to measure performance and some variables. The data of Table 1 come from CSMAR database. CSMAR means database of financial data and marketing data of China capital market. CSMAR database includes all financial data and marketing data of A-share listing companies in Shanghai Stock Exchange and Shenzhen Stock Exchange since 1990 . In the regressions, purchase costs and employee value are measured as $\ln$ (fees paid to acquire) and In(total Assets in 2007/employee number in 2007), respectively.

Tobin's Q: Tobin's Q = (Market value of the firm + Book value of the debt)/Book value of total assets. Market value of the acquiring firm's assets divided by book value of its assets for the fiscal year prior to the acquisition. The market value of assets is equal to book value of assets plus market value of common stock minus book value of common stock minus balance sheet deferred taxes. Tobin $\mathrm{Q}$ is used as indicators of performance, which takes goodwill, patents and other intangible assets into account. Tobin Q measures company's future cash flows and discounted value.

CEO duality: Chairman-CEO duality has been considered as 
Table 1.

Variable definition table.

\begin{tabular}{|c|c|c|c|}
\hline Variable & Index & Symbol & Definition \\
\hline \multirow[t]{3}{*}{$\begin{array}{l}\text { Dependent } \\
\text { variable }\end{array}$} & Market Value & TBQ & Tobin's Q \\
\hline & Board size & BS & $\begin{array}{l}\text { Directors number in } 2007 \\
\text { annual report }\end{array}$ \\
\hline & Shareholders' degree & SD & $\begin{array}{l}2007 \text { annual report, the } \\
\text { three major shareholding/ } \\
\text { the largest shareholder } \\
\text { proportion }\end{array}$ \\
\hline \multirow{4}{*}{$\begin{array}{l}\text { Explanatory } \\
\text { variables }\end{array}$} & Institutional investors & II & $\begin{array}{l}2007 \text { annual report } \\
\text { disclosure of the fund's } \\
\text { holdings and/Fund number }\end{array}$ \\
\hline & Chairman-CEO duality & CC & $\begin{array}{l}\text { Chairman and general } \\
\text { manager are the same } \\
\text { person, dummy variable }\end{array}$ \\
\hline & Time to market & $\mathrm{TM}$ & $\begin{array}{l}\text { Companies listed on the } \\
\text { relative value of time to } \\
2008\end{array}$ \\
\hline & Purchase shares & PS & $\begin{array}{l}\text { the shares of the Target } \\
\text { Company }\end{array}$ \\
\hline \multirow[t]{3}{*}{$\begin{array}{c}\text { Control } \\
\text { variables }\end{array}$} & Purchase costs & PC & $\begin{array}{c}\ln (\text { Fees paid to acquire } \\
\text { shares) }\end{array}$ \\
\hline & Cost per & СР & $\begin{array}{l}\text { Purchase price/purchase } \\
\text { shares }\end{array}$ \\
\hline & Employee value & EV & $\begin{array}{l}\ln (2007 \text { Assets/2007 } \\
\text { number of employees) }\end{array}$ \\
\hline
\end{tabular}

a dummy variable in the regressions. " 1 " has been given to firms having CEO non-duality and "0" Otherwise.

Firms' ability: As a measure of firm size, we used the number of employees and total assets, taken at before one year of the M\&A. The number of employees and total assets are always expressed in logarithm terms.

Firm's age: We measured the age of the firms, from being a listed company, at the year of the M\&A.

Target size: The acquisition of a company with a large volume of assets or number of employees is characterized with high levels of complexity and more diverse product portfolio, so integration procedures and routines will differ from those for small targets, increasing risks and uncertainties. Besides, the value of target firms in large M\&A can be more difficult to capture than in small one (Ellis et al., 2011).

\section{Statistical Description and Correlation Analysis}

In this paper, the date is analysis by statistical software (SPSS20.0 and EVIEWS6.0). First, we analyze the data with descriptive statistics. Second, we analyze the correlation of variables. In the end, assumptions are tested by the multiple regression models.

Table 2 shows statistical description of each variable, including mean, median, minimum, maximum and standard deviation. The Chairman-CEO duality is a dummy variable. $\mathrm{CC}=1$, if the chairman and the CEO are the same one; $\mathrm{CC}=0$, otherwise. From Table 2.

Table 3 shows the correlation between each variable and all the variables. It is easy to see that the value of the company in 2011 with 2007 employees get the highest correlation coefficient reach to 0.474 . The low correlation coefficient among
Table 2.

Descriptive statistics.

\begin{tabular}{cccccc}
\hline Variable & Mean & Median & Maximum & Min & SD \\
\hline TM & 14.830 & 15.500 & 19.000 & 4.000 & 2.920 \\
II & 0.5300 & 0.390 & 1.760 & 0.000 & 0.719 \\
PS & 56.34 & 55.00 & 100.00 & 5.080 & 35.86 \\
PC & 7.960 & 7.930 & 8.960 & 6.690 & 0.650 \\
EV & 4.068 & 4.013 & 6.107 & 2.505 & 0.911 \\
CC & 0.110 & 0.000 & 1.000 & 0.000 & 0.320 \\
BS & 8.440 & 9.000 & 11.000 & 5.000 & 1.560 \\
SD & 1.511 & 1.386 & 2.562 & 1.022 & 0.436 \\
TBQ & 1.250 & 0.980 & 3.100 & 0.680 & 0.620 \\
\hline
\end{tabular}

Table 3.

Correlation coefficients.

\begin{tabular}{ccccccccc}
\hline Variable & TBQ & II & TM & EV & PS & CC & SD & BS \\
\hline TBQ & 1 & & & & & & & \\
II & -0.42 & 1 & & & & & & \\
TM & 0.286 & 0.037 & 1 & & & & & \\
EV & 0.474 & -0.018 & -0.108 & 1 & & & & \\
PS & 0.11 & -0.404 & -0.398 & 0.292 & 1 & & & \\
CC & 0.339 & 0.127 & -0.144 & 0.358 & 0.16 & 1 & & \\
SD & 0.12 & -0.078 & -0.098 & 0.078 & 0.127 & 0.13 & 1 & \\
BS & -0.828 & 0.191 & 0.054 & -0.976 & -0.382 & -0.55 & -0.158 & 1 \\
\hline & & & & & & & &
\end{tabular}

independent and control variables and acceptable variance inflation factor statistics suggest that multicollinearity of variables is not a problem in our model.

\section{Model Results}

To test four hypotheses, this paper uses the OLS model as follows:

Model A: check-balance ownership structure and Tobin's Q

$T B Q$

$$
\begin{aligned}
=\partial & +\beta_{1} \times S D+\beta_{2} \times T M+\beta_{3} \times E V+\beta_{4} \times C P+\beta_{5} \times P S \\
& +\beta_{6} \times C C+\beta_{7} \times P C+\varepsilon
\end{aligned}
$$

Model B: board size and Tobin's Q

$T B Q$

$$
\begin{aligned}
=\partial & +\beta_{1} \times B S+\beta_{2} \times T M+\beta_{3} \times E V+\beta_{4} \times C P+\beta_{5} \times P S \\
& +\beta_{6} \times C C+\beta_{7} \times P C+\beta_{8} \times P B S+\varepsilon
\end{aligned}
$$

Model C: Institutional Investors and Tobin’s Q

\section{$T B Q$}

$$
\begin{aligned}
=\partial & +\beta_{1} \times I I+\beta_{2} \times T M+\beta_{3} \times E V+\beta_{4} \times C P+\beta_{5} \times P S \\
& +\beta_{6} \times C C+\beta_{7} \times P S+\varepsilon
\end{aligned}
$$

where:

$\partial$ : Constant.

$\beta_{\mathrm{i}}$ : the coefficient of each variable.

$\varepsilon$ : residual.

The results are shown in Table 4. 
Table 4.

The model of multiple linear regression results ${ }^{1}$.

\begin{tabular}{|c|c|c|c|}
\hline Variable & Model A & Model B & Model C \\
\hline \multirow{2}{*}{ C } & 1.257 & 10.423 & 0.984 \\
\hline & $(-1.027)$ & $(-4.207)$ & $(-0.812)$ \\
\hline \multirow{2}{*}{ SD } & 0.287 & & \\
\hline & $(-1.461)$ & & \\
\hline \multirow{2}{*}{ BS } & & -0.585 & \\
\hline & & $(-4.168)$ & \\
\hline \multirow{2}{*}{ PBS } & & -3.087 & \\
\hline & & $(-3.903)$ & \\
\hline \multirow{2}{*}{ II } & & & -0.197 \\
\hline & & & $(-1.709)$ \\
\hline \multirow{2}{*}{$\mathrm{TM}$} & 0.091 & 0.076 & 0.086 \\
\hline & $(-3.145)$ & $(-3.173)$ & $(-3.047)$ \\
\hline \multirow{2}{*}{ EV } & 0.230 & 0.123 & 0.245 \\
\hline & $(-2.309)$ & $(-1.370)$ & $(-2.503)$ \\
\hline \multirow{2}{*}{ СР } & -0.832 & -1.032 & -0.803 \\
\hline & $(-1.984)$ & $(-2.972)$ & $(-1.964)$ \\
\hline \multirow{2}{*}{ PS } & -0.010 & -0.010 & -0.009 \\
\hline & $(-2.566)$ & $(-3.333)$ & $(-2.375)$ \\
\hline \multirow{2}{*}{ PC } & -0.250 & -0.179 & -0.157 \\
\hline & $(-1.877)$ & $(-1.633)$ & $(-1.225)$ \\
\hline \multirow{2}{*}{ CC } & 0.605 & 0.471 & 0.671 \\
\hline & $(-2.163)$ & $(-2.010)$ & $(-2.414)$ \\
\hline R-squared & 0.528 & 0.691 & 0.540 \\
\hline F-statistic & 4.474 & 7.544 & 4.695 \\
\hline DW & 1.861 & 1.987 & 2.231 \\
\hline
\end{tabular}

As can be seen from Table 4, in these three variables, T-statistic is statistically significant at a 95\% confidence level. What's more, goodness of fit well reflected the reality. Meanwhile DW test value is around 2.0, avoiding multicollinearity and autocorrelation.

Model A shows insignificant coefficient for ownership structure, and the hypothesis 1 is supported. The check-balance ownership structure has a significantly positive correlation. The cooperation between the second and the third largest shareholder will limit the largest shareholder.

The result in Model B shows that board size has significant effects. BS negatively related to the long-term M\&A performance, which verifies the hypothesis 1 of this study. This means that if the enterprises have larger board members, the performance of mergers and acquisitions will be decreased. Besides, majority interests are often easy to be captured by a few people, so individual rationality succumb to the overall irrationality, making compromise decisions. One would realize that the size of board in terms of quantity is materially insignificant compared to the quality which determines effectiveness of corporate deliberations and decision making.

The outcome of Model C shows that Institutional investors

${ }^{1}$ Unstandardized coefficients are shown, with standard errors next to them. have positive and significant effects on M\&A performance, so Hypotheses 3 is supported. Institutional investors have negative relationship with the long-term performance of M\&A. Institutional investors are tend to accomplice with the company's managers for their own interests.

Hypothesis 4 proposes that Chairman-CEO duality is positive related to M\&A. In China's national conditions, we can consider that Chairman-CEO duality bring long-term performance improvements. Empirical evidence has shown negative correlation between the paid for the acquisition and the acquisition of long-term performance.

\section{Robustness Test}

In order to prove the reliability of the above conclusions, the following tests as follows:

1) Refer to Shao \& Yu (2012) research method about the calculation of non-tradable shares, Tobin's $Q$ is calculated by the market value in circulation $25 \%$ discount.

2) When it comes to SD, I use the total shares of top ten shareholders replace the top three shareholders.

Taken together, the conclusions of this paper have not been materially affected, except that an indicator (TM) is a slight change in the significance level, so the conclusions are reliable.

\section{Conclusions and Implications}

The conclusions of the real estate industry mergers and acquisitions under economic crisis give us some inspiration. Eddie Hui C. M. et al. (2011) found that there are positive correlation between real estate market and stock market in the United Kingdom and in Hong Kong, from 1993 to 2007. The paper explains the similarities by two transmission mechanisms: wealth effect and credit-price effect. To analyze the influence of corporate governance on long-term performance of M\&A transactions, this paper uses an empirical model. With the development of the security market and the growing power of the enterprises, the M\&A is becoming increasingly popular. There is a misunderstanding in the mergers and acquisitions of listed companies in China which is in order to mergers and acquisitions and to mergers and acquisitions, and there is very little detailed analysis to the predicted results after mergers and acquisitions, which led to a doubt of creating value to mergers and acquisitions as theoretically speaking. Many scholars own different opinions to the thing that whether it can create value for our listed companies in mergers and acquisitions. So basing on the previous studies, this article researches the performance of the mergers and acquisitions of listed companies, which will own an important practical significance.

Through practical studies and analysis, following conclusions could be summarized from this thesis: These results suggest that the concentrated ownership alignment effect dominates the entrenchment motives and acts as a deterrent mechanism to prevent controlling shareholders from managing earnings in stock-financed M\&A. Besides, State-owned enterprises should take full advantage of social market economy, improving their own internal checks and balances and the equity voting system.

The Board inefficient results in the failure of bringing benefits to the company, taking the limitation of the rights and interest of independent directors into account who fail to play their roles. In China's financial markets, institutional investors 
who engage in speculative activities will spare no effort in pushing stock prices up for their own interest.

The paper has several implications for managerial practice. Notably, it suggests that the company that intends to perform acquisition with the aim of company value must take care of the decisions. Moreover, investors can predict or prevent some risks by valuing firm's some characteristics such as board and CEO duality. Linda M. Cohen (2010) pointed that better understanding how physical asset decisions can affect M\&A outcomes, and how these assets can be used as a powerful tactical and strategic resource, will help managers achieve desired outcomes when faced with M\&A.

There are some limitations in this paper: 1 ) the lack of contrast to the company that did not merger other firms; 2) the failure of giving a full consideration of the all the factors that may influence the performance, such as organizational structure, marketing. It would be much better for me to improve this paper with the help of questionnaire survey.

\section{REFERENCES}

Abidin, Z. Z., Kamal, N .M., \& Jusoff, K. (2009). Board structure and corporate performance in Malaysia. International Journal of Economics and Finance, 1, 150-164.

Adams, R. B., Almeida, H., \& Ferreira, D. (2005). Powerful CEOs and their impact on corporate performance. Review of Financial Studies, 18, 1403-1432. http://dx.doi.org/10.1093/rfs/hhi030

Bello, L. (2012). Board dynamics and corporate performance: Review of literature, and empirical challenges. International Journal of Economics and Finance, 4, 22-35.

Ben-Amar, W., \& André, P. (2006). Separation of ownership from control and acquiring firm performance: The case of family ownership in Canada. Journal of Business Finance \& Accounting, 4, 517-543. http://dx.doi.org/10.1111/j.1468-5957.2006.00613.x

Coles, J., McWilliams, V., \& Sen, N. (2001). An examination of the relationship of governance mechanisms to performance. Journal of Management, 27, 23-50.

http://dx.doi.org/10.1177/014920630102700102

Das, A., \& Kapil, S. (2012). Explaining M\&A perfomance: A review of empirical research. Journal of Strategy and Management, 5, 284330. http://dx.doi.org/10.1108/17554251211247580

Zhong, D. C., \& Long, G. S. (2012). Mergers and acquisitions for business growth and its mechanism analysis. Financial and Economic Issues, 12, 102-109.

Dwivedi, N., \& Jain, A. K. (2005). Corporate governance and performance of Indian firms: The effect of board size and ownership. Employee Responsibilities and Rights Journal, 17, 161-172. http://dx.doi.org/10.1007/s10672-005-6939-5

Ellis, K. M., Reus, T. H., Lamont, B. T., \& Ranft, A. L. (2011). Transfer effects in large acquisitions: How size-specific experience matters. The Academy of Management Journal, 54, 1261-1276. http://dx.doi.org/10.5465/amj.2009.0122

Fan, J. P. H., \& Wong, T. J. (2005). Do external auditors perform a corporate governance role in emerging markets? Evidence from East Asia. Journal of Accounting Research, 43, 35-72. http://dx.doi.org/10.1111/j.1475-679x.2004.00162.x

Francoeur, C., Amar, W. B., \& Rakoto, P. (2012). Ownership structure, earnings management and acquiring firm post-merger market performance. International Journal of Managerial Finance, 8, 100-119. http://dx.doi.org/10.1108/17439131211216594

Fu, Q., \& Hao, Y. (2012). Ultimate controller, control is transferred to investment efficiency. Economics and Management, 11, 5-16.

Garg, A. K. (2007). Influence of board size and independence on firm performance: A study of Indian companies. Vikalpa, 32, 39-60.

Guo, L. J., \& Chen, H. M. (2013). Macro listed real estate companies in China under the performance evaluation. Accounting, 3, 72-75.

Goranova, M., Dharwadkar, R., \& Brandes, P. (2010). Owners on both sides of the deal: Merger and acquisitions and overlapping institutional ownership. Strategic Management Journal, 31, 1114-1135. http://dx.doi.org/10.1002/smj.849

Hagendorff, J., \& Keasey, K. (2009). Post-merger strategy and performance: Evidence from the US and European banking industries. Accounting \& Finance, 49, 725-751. http://dx.doi.org/10.1111/j.1467-629X.2009.00306.x

Haniffa, R., \& Hudaib, M. (2006). Corporate governance structure and performance of malaysian listed companies. Journal of Business Finance and Accounting, 33, 1034-1062. http://dx.doi.org/10.1111/j.1468-5957.2006.00594.x

Hermalin, B. E., \& Weisbach, M. S. (2003). Boards of directors as an endogenously determined institution: A survey of the economic literature. FRBNY Economic Policy Review, 4, 7-26.

Heracleous, L. (2001). What is the impact of corporate governance on organizational performance? Corporate governance. An International Review, 9, 165-173.

$\mathrm{Hu}$, Z. H. (2012). Mergers and acquisitions board characteristics and shareholder wealth research. Economic Issues, 11, 141-146.

Jackling, B., \& Johl, S. (2009). Board structure and firm performance: Evidence from India's top companies. Corporate Governance: An International Review, 17, 492-505. http://dx.doi.org/10.1111/j.1467-8683.2009.00760.x

Jiang, H., \& Liu, X. (2012). Blockholders major shareholders of listed companies M\&A performance. Southern Economy, 9, 32-46.

Lei, G., \& Song, S. (2008). Management ownership and firm performance: Empirical evidence from the panel data of Chinese listed firms between 2000 and 2004. Frontiers of Business Research in China, 2, 372-384. http://dx.doi.org/10.1007/s11782-008-0022-7

Cohen, L. M. (2010). Physical assets in the M\&A mix: A strategic option. Journal of Business Strategy, 31, 28-36. http://dx.doi.org/10.1108/02756661011089053

Cashen, L. H. (2011). Board leadership structure under fire: CEO duality in the post-restructuring period. Academy of Strategic Management Journal, 10, 1-16.

Raluca-Georgiana (2013). Does CEO duality really affect corporate performance? International Journal of Academic Research in Economics and Management Sciences, 2, 156-165.

Masulis, R. W., Wang, C., \& Xie, F. (2007). Corporate governance and acquirer returns. Journal of Finance, 62, 1851-1889.

Gill, M. S., Vijay, T. S., \& Jha, S. (2009). Corporate governance mechanisms and firm performance: A survey of literature. The IUP Journal of Corporate Governance, 8, 7-22.

Mehrdad, A., \& Hossein, A. (2011). The effect of ownership structure on corporate performance of listed companies in Tehran stock exchange: An empirical evidence of Iran. International Journal of Business and Social Science, 2, 49-55.

Mak, Y. T., \& Yuanto, K. (2003). Size really matters: Further evidence on the negative relationship between board size and firm value. $\mathrm{Pa}$ cific-Basin Finance Journal, 13, 301-318. http://dx.doi.org/10.1016/j.pacfin.2004.09.002

Saibaba, M. D. (2013). Do board independence and CEO duality matter in firm valuation?-An empirical study of Indian companies. The IUP Journal of Corporate Governance, 12, 50-67.

OECD (2004). OECD principle of corporate governance. Paris: OECD.

Perry, T., \& Shivdasani, A. (2005) Do boards affect performance evidence from corporate restructuring. Journal of Business, 78, 14031431. http://dx.doi.org/10.1086/430864

Phalippou, L., \& Gottschalk, T. (2009). The performance of private equity funds. The Review of Financial Studies, 22, 1747-1776.

Rani, N., Yadav, S. S., \& Jain, P. K. (2013). Post-M\&A operating performance of indian acquiring firms: A Du Pont analysis. International Journal of Economics and Finance, 5, 65-73. http://dx.doi.org/10.5539/ijef.v5n8p65

Raheja, C. G. (2005). Determinants of board size and composition: A theory of corporate boards. Journal of Financial and Quantitative Analysis, 40, 1-38. http://dx.doi.org/10.1017/S0022109000002313

Sarkar, J., \& Sarkar, S. (2000). Large shareholder activism in corporate governance in developing countries: Evidence from India. International Review of Finance, 1, 161-194. 
http://dx.doi.org/10.1111/1468-2443.00010

Silveira, A. M., \& Dias Jr., A. L. (2010). What is the impact of bad governance practices in a concen-trated ownership environment? International Journal of Disclosure and Governance, 7, 70-91. http://dx.doi.org/10.1057/jdg.2009.21

Shao, Y. P., \& Yu, F. F. (2012). Internal capital markets related transactions and corporate value. China Industrial Economy, 4, 102-114.

Sulong, Z., \& Nor, F. M. (2010). Dividends, ownership structure and board governance on firm value: Empirical evidence from Malaysian listed firms. Malaysian Accounting Review, 7, 55-94.

Horner, S. V. (2010). Board power, ceo appointments And CEO duality. Academy of Strategic Management Journal, 9, 43-58.

Wang, L.J., \& Tong, X.W. (2008). Private listed companies control type, diversification and firm performance. Nankai Business Review, 11, 31-39.

Wang, K., \& Xiao, X. (2005). Empirical study: Institutional ownership and related parties' occupation. Nankai Management Review, 2, 2733.

Wenjuan Zuo., \& Lun Hu. (2011). Examining the relationship between real estate and stock markets in Hong Kong and the United Kingdom through data mining. International Journal of Strategic Property Management, 15, 26-34.

http://dx.doi.org/10.3846/1648715X.2011.565867

Li, Y. Z., \& Wei, J. (2011). An empirical study: Heterogeneity of institutional investors and large shareholders' benefits transportation. Management \& Engineering, 2, 1838-5745.

Qu, Y. (2011). Mergers and acquisitions, executives and corporate performance characteristics. Zhejiang Finance, 12, 62-65.

Daraghma, Z. M. A., \& Alsinawi, A.-A. (2011). Board of directors, management ownership, and capital structure and its effect on performance: The case of palestine securities exchange. International Journal of Business and Management, 5, 118-127. 